\title{
Analysis of Supplementary Reading Material Based on Students' Preference
}

\author{
Vavia Darmayanti \\ Postgraduate Student of English Education Study Program, Bengkulu University, Indonesia \\ vavia.darmayanti7@gmail.com \\ Syahrial \\ Lecturer of Postgraduate of English Education Study Program, Bengkulu University, \\ Indonesia \\ syahrial@unib.ac.id \\ Wisma Yunita \\ Lecturer of Postgraduate of English Education Study Program, Bengkulu University, \\ Indonesia \\ wismayunita@unib.ac.id \\ Corresponding email: vavia.darmayanti7@gmail.com
}

\begin{abstract}
The aims of this study were to find out the types of text of supplementary reading material chosen by students based on their preference and to investigate the students' reasons in choosing the types of text of supplementary reading material at grade VIII of SMPN 1 Kepahiang. This research was categorized as descriptive quantitative and qualitative research. The subjects were the students of grade VIII who are chosen by using semi random sampling. The data was collected by using text types list and open ended questions. The researcher asked the students to choose types of text which were prefered by them, from total 50 texts the students must choose twenty texts. Then, to know the reason why they chose those texts, the researcher did an open ended questions to 20 students randomly. There were two findings of this research; (1) the type of text for supplementary reading material chosen by mostly students based on their preference at grade VIII of SMPN 1 Kepahiang was narrative text; (2) there were three students' reasons in choosing the types of text for supplementary reading material at grade VIII of SMPN 1 Kepahiang, they were; the narrative text contains some stories which can entertain them, the narrative text is interesting to read, and the narrative text is easy to understand. Due to the limited sample taken in this research and the situation on Covid-19, it was suggested for further researcher to conduct similar research in more numbers of sample by conducting research in the classroom directly.
\end{abstract}

Keywords: Supplementary Reading Material, Text Types

\section{A. Introduction}

Reading is one of the receptive skills where meaning is extracted from discourse. Students will get maximum benefit in both extensive and intensive reading. Both extensive and intensive reading approaches are effective and have their own advantages in foreign language learning process for that reason a well-balanced reading program should include intensive reading and extensive reading concurrently. They are taught to read the 
foreign language with direct apprehension of meaning, without a conscious effort to translate what they are reading. Reading skill is the most important activity in any language class, not only as a source of information and a pleasurable activity, but also as a means of consolidating and extending one's knowledge of the language (Rivers, 1981). Through reading skill, students can increase their understanding and knowledge of the language.

Reading is one of the language skills which is very important to be learned by students (Handyani, et al. 2020; Dhilon, et al. 2020; Martina, et al. 2020). Through this activity, students can improve their own language and experience. They will get information and ideas which they need to know (Syafryadin et al, 2020). Since reading becomes one of important skill should be acquired by the students, the teachers must be selective in choosing suitable reading material for the students which is related to literacy. Literacy is the ability to read for the purpose of discerning information from the written words (Yunita, 2012). Berardo (2006) identifies some factors for well selecting materials to be used in the classroom. First, suitability of content which means that teachers should select those materials that are relevant and stimulate learners' interest. Also, exploitability where teachers should set the purpose and the skills to be developed by exploiting the materials, thus improving student's competence. Moreover, readability which means suitability of language in terms of structural and lexical difficulty and new vocabulary. Finally, presentation, materials should grab learners' attentions, and represent the type of materials that the learners will encounter or use outside (Syahrial et al, 2018).

Supplementary materials refer to the materials which are taken from another source or any other materials that are designed to support the teaching and learning process. Besides, supplementary materials are not only useful for the students but also the teachers. Moreover, Reddy (2003) also states that there are several benefits of supplementary material, namely: foster creativity, encourage the students' excitement, break monotonous activities of the class, encourage situational English, enhance language skills and communication skills, lead to group work, and task can be challenging.

As the researcher's experience in teaching English at SMPN 1 Kepahiang, the researcher found that the English teachers face a serious problem related to the teaching and learning English in the classroom especially reading skill. One of them is the limitation of reading material represented in the K13 textbook. The teachers assumed that they have 
Jadila: Journal of Development and Innovation

in Language and Literature Education

Publisher: Yayasan Karinosseff Muda Indonesia
E-ISSN: 2723-6900

P-ISSN: 2745-9578

Volume:. 1 Number 32021

Page: $271-.283$

limited reading material represented in the Curriculum 13 textbooks published by the Government, since the textbook dominantly contains speaking materials. There are many dialogues found in the textbook, while there is only a few text or passages included in the textbook. As matter of fact, final examination questions for English subject mostly consist of some text types or kinds of text every year. The questions are usually built up or asked based on the text or passage. Moreover, a study by Derinenta and Mahripah (2016) entitled Designing English Reading Materials as a Supplementary Book for the Seventh Grade Students of SMP Aloysius Denggung in the First Semester also mentioned that the supplementary materials for reading was still needed to be developed especially for junior high school level of students. Due to the important of supplementary reading materials to facilitate teaching and learning process in English class, therefore the researcher conducted a research entitled "Analysis of Supplementary Reading Material based on Students' Preference".

\section{B. Research Methodology}

This research was categorized as mixed method which means that the combination of quantitative and qualitative research (Cresswell, 2014). The type of mixed method used was model sequential which means the researcher used quantitative firtsly then qualitative. It is used to describe the text types prefered by the students. The population of this study were all of grade eigth students of SMPN 1 Kepahiang. The students of grade VIII were chosen by using semi random sampling to decide the sample of this research, because it was impossible to use random sampling (Sugiyono, 2001). Semi randomly sampling is conducted by random sampling the five class of VIII grade of SMPN 1 Kepahiang; class C, D, E, F, G, and H and then the class that have been chosen got the texts that developed by the researcher.

The data were collected by using text types sheet and open ended questionnaire. The procedures were; (1) The researcher asked the students to choose types of text which were prefered by them. From the total of 50 texts, the students must choose twenty texts. (2) The researcher used 50 texts which were divided into narrative, descriptive, procedure, report, and recount. (3) Then, to know the reasons why they chose those texts, the researcher asked questions to students randomly. The researcher used theory from Arikunto (2009) in taking the sample of interview. The researcher took the sample of interview from $15 \%$ of sample which were about 20 students from total 169 sample of students. In analyzing the data the 
researcher categorized the text chosen by the students based on their preferences then the researcher analyzed the students' reasons in choosing those text by the result of open ended questions. In analyzing quantitative data, the researcher used percentage formula to calculate the text type prefered by students The open ended question result was analyzed by using some steps from Miles, Huberman, \& Aldana (2004). The data analysis consists of three main components, namely: (1) data reduction; (2) data display; and (3) drawing and verifying conclusion.

\section{Results and Discussion}

\section{Results}

This research aimed to find out the types of text of supplementary reading material chosen by students based on their preference and to investigate the students' reasons in choosing the types of text of supplementary reading material at grade VIII of SMPN 1 Kepahiang. The researcher gave the students 50 texts which were divided into five types; descriptive, narrative, procedure, recount, and report text to know their preference toward type of text used in reading English. The researcher describes the result of this research into two sub-bab; the types of text of supplementary reading material chosen by students based on their preference and the students' reasons in choosing the types of text of supplementary reading material.

\section{The Types of Text of Supplementary Reading Material Chosen by Students Based on Their Preference}

The researcher gave 50 texts to the students to know their preference toward five types of text used in reading English material. The result revealed that there were seven texts which were choosen above 100 students. The types of that seven texts were text 2 (118), text 23 (114), text 6 (113), text 3 (109), text 11 (102), text 22 (101), and text 25 (100). However, there was no students who chose recount and procedure text above 100. The result also showed that 61 students chose text 1, 118 students chose text 2, 109 students chose text 3, 68 students chose text 4, 82 students chose text 5,113 students chose text 6,50 students chose text 7, 89 students chose text 8,35 students chose text 9,21 students chose text 10 . Then there were 102 students chose 11,76 students chose text 12,79 students chose text 13,61 students chose text 14 students chose text 15,89 students chose text 16 , students chose text 17, 58 students chose text 18 . There were 44 students who chose text 19 and 38 students 
chose text 20. There were 65 students chose 21,101 students chose text $22,11 \quad 40$ nts chose text 23, 92 students chose text 24, 100 students chose text 25, 76 students chose text 26, 54 students chose text 27,53 students chose text 28 . There were 59 students who chose text 29 and 71 students chose text 30 . The result showed that the students mostly chose text 2 as prefered text based on their interest. Text 2 was narrative text entitled "the Cows and the Lion". There were seven texts which choosen by more than one hundred students and rest of them were below one hundred. Moreover, to know the the preference text types choosen by the students, see the table below.

Table 1 Types of Text based on Students' Preferences

\begin{tabular}{|c|c|c|}
\hline Types of Text & $\mathbf{F}$ & $\%$ \\
\hline Descriptive & 717 & $21,20 \%$ \\
\hline Recount & 579 & $17,12 \%$ \\
\hline Report & 675 & $19,95 \%$ \\
\hline Narrative & 730 & $21,58 \%$ \\
\hline Procedure & 681 & $20,13 \%$ \\
\hline Total & 3382 & $100 \%$ \\
\hline
\end{tabular}

Table 1 showed that there were $21,20 \%$ of students chose descriptive as their preference text type, then $17,12 \%$ of students chose recount text, $19,95 \%$ of students chose report text, $21,58 \%$ of students chose narrative text, and $20,13 \%$ of students chose procedure text. Moreover, this research found that mostly the students chose narrative text as their preference text types.

\section{The Students' Reasons in Choosing the Text}

After the researcher found the type of text preference by students, the researcher asked their reasons by using open ended questionnaire. The researcher asked 20 students as the sample of open ended questions to know why they chose narrative text as their preference text types. Narrative text is a type of text in the form of imaginary stories, engineered true stories, or fairy tales. Narrative text tells a story that has a series of chronological events that are interconnected. The purpose of narrative text is to entertain the reader (Anderson and Anderson, 2003). Then the researcher analyzed and interpreted the result of questionnaire. 
The researcher found that there were some reasons in choosing narrative text as the students' preference text types, First, the narrative text contains some stories which can entertain them. As student 1 said "narrative text can intertain readers about a story or story" (DSA). Another student also said "narrative text contains some folktale and legend and frumn story" (NAF). Moreover, student 6 said "Maybe students want to read Something tha imunu them entertained, because the purpose of the narrative text itself makes the reader entertained". For example, story about the foolish donkey which can entertain them while reading. From 20 students, there were 12 students who agreed that the narrative text can entertain them.

Second, the narrative text is interesting text. Fifteen students answered that narrative text was interesting to be read. As student 3 said "the narrative text is interesting for readers who will be able to grow someone thinking creatively and actively" (RH). Another student said that Maybe because narative texts are more directed to stories and interesting experience that are more exciting when read. For example, the story about the man and two sweethearts has interesting story for them.

The third reason, sixteen students said that the narrative text is easy to understand. As student 4 said that narrative text is easy to understand and this text has something in common. For texts that are commonly studied in Indonesian language lessons, this text also has a structure that is easy to understand and this text is liked because it can entertain the reader. And the rest four other students also answered that narrative text is easier to understood rather than other text types. For example, the language used in the story was easy to understand since it was familiar among students.

To conclude, there were three students' reasons in choosing narrative text type as their preference. First, the narrative text contains some stories which can entertain them. Second, the narrative text is interesting to read, and the narrative text used ;language which is easy to understand.

\section{Discussion}

There were two findings of this research. The first, the type of text for supplementary reading material chosen by mostly students based on their preference at grade VIII of SMPN 1 Kepahiang was narrative text. The second, there were three students' reasons in choosing the types of text for supplementary reading material at grade VIII of SMPN 1 Kepahiang, 
they were; the narrative text contains some stories which can entertain them, the narrative text is interesting to read, and the narrative text is easy to understand.

\section{The Types of Text For Supplementary Reading Material Chosen by Students Based on Their Preferences at Grade VIII of SMPN 1 Kepahiang}

The finding of this research showed that the type of text for supplementary reading material chosen by most students based on their preference at grade VIII of SMPN 1 Kepahiang was narrative text. The finding of this research was supported by Meyers (2005 : 52) who states that narrative is one of the most powerful ways of communicating with others. A good written story lets your reader response to some event in your life as if it were own. They not only understand the event, but they can almost feel it. The action, details, and dialogue put the readers in these seem and make it happen for them. Moreover, Anderson (1997 : 8) states that narrative is a piece of text tells a story and, in doing so, entertains or informs the reader or listener.

In Curriculum 2004 narrative text is defined as a text which function is to amuse, entertain, and to deal with actual or various experience in different ways. Narrative deals with problematic event lead to a crisis or turning point of some kind in turn finds a resolution. Whereas Anderson and Anderson (2003), they state that narrative is a piece of the text which tells a story and entertains or informs the reader. Some examples of narrative text are fantasy novels, bed time stories (spoken), historical fiction, and stories. In others, Djuhari (2008) states that narrative text is kind of text about story or fairy tale which has purposed to entertain the reader. The main characteristic of a narrative text is about the problem and how to solve the problem, which is like a solution. Narrative text content is about fantasy or event true story which has been added some engineering story.

Narrative text is a type of text which has been employed since the very old times throughout the history. Even if time and cultural differences have caused various changes, narrative text genre has elements, which can be determined in a concrete manner and also people have the same expectations in terms of text structure (Coşkun, 2005). According to Bruner (1986), the narrative texts can be formed of active and serial events, emotional events or a mixture of both. Stories dealing with successive events are generally was by a third person. Story is consisted of a sequence of events and events are was according to order of happening. Protagonist's psychological structure is not emphasized on so much in such kind of stories because it is much easier to understand it (Westbay, 1999). Stories dealing with both feelings and conscience aspect of characters are more complex. Such kind of stories is 
written through different characters' points of view, which requires reader to understand the psychological motivation of a main character. These stories are extremely difficult to understand since it is obligatory to interpret other people's behaviors given their own purposes and perspectives.

The learners need to read English texts. It is through reading that the learners acquire the inputs for language acquisition such as vocabulary and language rules. As the result from reading, they obtain information to expand their ability to learn other skills. It is supported by Harmer (2007:99) who said, "Reading is useful for language acquisition. Provided that students more or less understand what they read, the more they read, the better they get at it." Appropriate text selection can pre-empt student disengagement and is, therefore, a critical step in teacher planning. Altman, Ericksen \& Pena-Schaff (2006) state that this selection process (for a textbook) should involve teachers examining graduate profiles, course objectives, time restrictions, teaching approaches and student abilities, and should draw on criteria for textbook selection. The criteria they suggest cover content (aspects of topic relevance, depth and timeliness of coverage, rigour and diversity) and pedagogy (layout, writing style, appropriateness for different learning styles, organisation, review points, glossary and relation of visual elements to text).

The finding showed that the students dominantly chose narrative text as their prefered text. It was similar to the research result by Sallabas (2013) entitled "Analysis of narrative texts in secondary school textbooks in terms of values education". Their investigation show that while narrative texts in these textbooks are rich in terms of such values like diligence, sensitiveness, and love, there are lack of certain values such as peace, tolerance, fairness, freedom, cleanness and hospitality.

\section{The Students' Reasons in Choosing The Types of Text of Supplementary Reading Material at Grade VIII of SMPN 1 Kepahiang}

The finding also showed that the reason why the students choose narrative text was because the narrative text can amuse them. It relates to the social function of the narrative text. The social function of narrative is to entertain to amuse, entertain and to deal with actual or various in different ways. Linda Gerot and Eignell (1994) says that the function of narrative text is to amuse entertain and to deal with actual or vicarious experience in different ways. It means that narrative text has functioned to entertain or to amuse the reader and to deal with actual or imaginative experience in different ways which shows by problem and resolution as the way to solve the problem and resolution as the way to solve problem before. 
Jadila: Journal of Development and Innovation

in Language and Literature Education

Publisher: Yayasan Karinosseff Muda Indonesia
E-ISSN: 2723-6900

P-ISSN: 2745-9578

Volume:. 1 Number 32021

Page: $271-.283$

A narrative can be fictional or true, as long as the story is clear and has correct grammar, spelling, and vocabulary. It also needs the writer to be focused and excited on the narrative for it to look good. Narrative deals with problematic events, which lead to a crisis or turning of some kind. Anderson and Anderson (1997:8), they state that the generic structure of narrative text consist of four parts. There are orientation, complication, sequence of events, and resolution.

Stories are important for people of all ages but they are vitally important for children. Given the fact, educating children through stories is the best strategy for enabling them to develop the desired behaviors. Besides, stories and novels enrich children's limited experience of life, give them opportunities to think upon variety of personalities via characters and contribute to the clarification of value judgments they are still developing. In this way, children's adjustment to social and cultural environment within which they live becomes a lot easier. In addition to this, stories and novels not only enable children to recognize the people in their country within the historical perspective and also provide materials on the people of other countries (Gürel et al., 2007).

Moreover, the result of this study was similar to the result of Panjaitan et al (2019) study entitled "Genre preferences in Reading Comprehension materials in first level English book of Senior High School". The result of the previous study revealed that genre preferences in the reading comprehension materials in first level English book senior high school was presented into three genre preferences: descriptive text, recount text, and narrative text. It was similar to the result of this present study which found that narrative text as the most preference text among students.

\section{Conclusion and Suggestion}

Based on the result of this research, there were two conclusions of this research: (1) The type of text for supplementary reading material chosen by mostly students based on their preference at grade VIII of SMPN 1 Kepahiang was narrative text. (2) There were three students' reasons in choosing the types of text for supplementary reading material at grade VIII of SMPN 1 Kepahiang, they were; the narrative text contains some stories which can entert ain them, the narrative text is interesting to read which means that the text can be imagined by the students while reading it, and the narrative text is easy to understand.

Due to the limited sample taken in this research and the situation on Covid-19, it was suggested for further researcher to conduct similar research in more numbers of sample by 
conducting research in the classroom directly. Moreover, further researcher can also use the findings of this research as reference to continue in developing supplementary reading material based on the students' preference.

\section{References}

Altman, W. S., Ericksen, K., \& Pena-Shaff, J. B. (2006). An inclusive process for departmental textbook selection. Teaching of Psychology, 33, 228-231. doi:10.1207/s15328023top3304_2

Alvermann, D., \& Earle, J. (2003).Comprehension instruction.In A. P. Sweet \& C. Snow (Eds.), Rethinking reading comprehension (pp. 12-30). New York: Guilford Press.

Anderson, M. \& Anderson, K. (1997). Text types in English 2. Macmillan Education Australia PTY, Ltd.

Anderson, M. \& Anderson, K. (2003). Text types in English 2. Macmillan Education Australia PTY, Ltd.

Arikunto, S. 2009. Prosedur penelitian suatu pendekatan praktik. Jakarta: PT Rineka Cipta

Beaugrande, R. de. \& W. U. Dressler. (1981). Introduction to text linguistics. London, New York: Longman.

Berardo, S. (2006). The use of authentic materials in the teaching of reading. The Reading Matrix Vol. 6, No. 2, September 2006

Brown, J. D. (2001). The elements of language curriculum: A systematic approach to program development. Boston: Heinle \& Heinle

Brindley, G. (1989). The role of needs analysis in adult ESL programme design. In R.K.Johnson (Ed.), The Second Language Curriculum. Cambridge: Cambridge University Press.

Cahyaningrum. (2015). Supplementary materials based on constructivism principles for students' effective learning.

Creswell, J. W. (2002). Educational research planning, conducting, and evaluating quantitative and qualitative research. Boston, MA Pearson.

Dhillon, B. P. S., Herman, H., \& Syafryadin, S. (2020). The Effect of Skimming Method to Improve Students' Ability in Reading Comprehension on Narrative Text. Linguists: Journal Of Linguistics and Language Teaching, 6(1), 77-88.

Fellowes, J., and Oakley, G. (2014). Language, literacy and early childhood education, 2nd Edition. Melbourne, Australia: Oxford University Press. 
Geoffrey, N. (2003). The effects of long-term vocabulary instruction on reading comprehension: A replication. Journal of Reading Behavior, 15, 3-18.

Gerot, L. \& Wignell, P. (1994). Making sense of functional grammar. Cammeray: Gerd Stabler.

Gürel Z, Temizyürek F, Şahbaz NK (2007). Children's literature. Ankara: Öncü Press

Gögüş B. (1978). Turkish and literature education in secondary schools. Ankara: Kadığlu Matbaas1.

Göktürk, A. (1997). Reading activity. İstanbul: Yapı Kredi Press

Grabe, W. \& Stoller, F.L. (2002). English language teaching: methods, tools, and technique. New York:Sunrise Publisher and Distribution.

Grellet, F. (2008). Developing reading skills. Cambridge, UK: Cambridge: University Press.

Günay, D. (2003). Text knowledge. İstanbul: Multilingual Press.

Handayani, S., Youlia, L., Febriani, R.B., Syafryadin, S. (2020). The use of digital literature in teaching reading narrative text. Journal Of English Teaching, Applied Linguistics And Literatures (JETALL). 3(2), 65-74.

Harmer, J. (2001). The practice of English language teaching. Third edition, London: Longman

Kirsch, I., de Jong, J., LaFontaine, D., McQueen, J., Mendelovits, J., \&Monseur, C. (2002). Reading for change: Performance and engagementacross countries. Paris: Organisation for Economic Co-operation and Development

Kirkpatrick, A., \& Mulligan, D. (2002). Cultures of learning: critical reading in the social and applied sciences. Australian Review of Applied Linguistics, 25(2), 73-99

Kitao, K., \& Kitao, S. K.(1997). College reading textbooks do not meet needs. The Daily Yomiuri, p. 7

Kurniasih. (2008). Vocabulary instruction for students with learning disabilities: A review of the research. Learning Disabilities Quarterly, 26, 117-128.

McGrath, I. (2013). Teaching materials and the Roles of EFL/ESL Teachers. London: Bloomsbury

Mcnamara, S. Daniel. (2007). Reading comprehension strategy. NewnYork: Taylor\& Francis Group, LLC 
MacKenzie, N., and Veresov, N. (2013). How drawing can support writing acquisition: Text construction in early writing from a Vygotskian perspective. Australasian Journal of Early Childhood, 38(4), 22-30.

Martina, F., Syafryadin, S., Rakhmanina, L., \& Juwita, S. (2020). The effect of time constraint on student reading comprehension test performance in narrative text. Journal of Languages and Language Teaching, 8(3), 323-329.

Matthews, B. and Ross, L (2010) . Research methods: a practical guide for the social sciences. Edinburgh: Pearson Education Ltd.

Meyers, A. 2005. Gateways to academic writing: effective sentences paragraph and essay. New York: Longman.

Noho. (2018). Developing supplementary English reading materials for Vocational High School.

Nurhani. (2017). Designing supplementary reading materials for the seventh graders of junior high school (a developmental research conducted at smp negeri 1 seyegan.

Panjaitan. (2019). Genre preferences in reading comprehension materials in first level english book of senior high school

Paulston, R. (2000). Why use textbooks? ELT Journal 36 (2), 104-111. Oxford Advanced Learner Dictionary. New York: Longman.

Reddy, R.S. (2003). Supplementary Materials to Enhance Language Skills of Learners. from indianresearch journals.com/pdf/IJSSIR/2019/September/16.pdf

Rivers, Wilga M. (1981). Teaching foreign language skills. Second Edition. Chicago and London: The University of Chicago Press.

Saenz LM, Fuchs LS (2002). "Examining the reading difficulty of secondary students with learning disabilities", Remedial Spec. Educ. 23(1):31-41

Sallabas. (2013). Analysis of narrative texts in secondary school textbooks in terms of values education.

Seyed Hossein Fazeli, M. e. (2010). Language in India:some Gaps in the current Studies of reading in Second/Foreign language learning. (Vol.10).issue4. (pp376-380

Sweet, A. P., \& Snow, C. E. (2003).Rethinking reading comprehension. New York: Guilford Press.

Syafriadin., Syafrizal., \& Wibowo, Y. (2020). An analysis of English teachers' strategies in teaching reading comprehension. 
Taşıgüzel S (2004). Aspect of collocational system in instructive texts in primary school Turkish course books, Lang. J. 125:72-87.

Woolley. G. (2011). Reading Comprehension: Assisting Children with Learning Difficulties. Retrieved from http://www.springer.com/cda/content/ document/cda_downloaddocument/9789400711730-c1.pdf?SGWID=0-0-451158048-p17410287

Yunita, W. (2012). Utilizing visual literacy in teaching english as a foreign language lbr university students. The 2nd UAD TEFL International Conference. 